\title{
Reactionary Technopolitics: A Critical Sociohistorical Review
}

\author{
Sean T. Doody
}

\section{| Introduction}

For many observers, Trump's steamrolling through the Republican Party establishment, his disregard for the institutionalized norms of political decorum, and his stunning defeat of Hillary Clinton seemingly came from nowhere, as if it were a "cataclysmic natural event we [were] powerless to prevent" (Kompridis 2006:247). And as the title of the symposium suggests, this cataclysm continues unfolding under Trumpian governance, a modality of rule highly abnormal for a representative democracy. While there are several abnormalities one could focus on in the Trump era, here I take aim at the disregard for truth and fact that haunts our present political moment. Donald Trump has made thousands of false statements—-big and small—over the course of his presidency (Dale 2019). At the same time, Trump enjoys a $92 \%$ approval rating among his Republican base - a figure that was unbruised by his impeachment trial and has increased since his acquittal (Gallup 2020). Moreover, Trumpian phraseology hostile to the concept of truthfrom "alternative facts" to "fake news" — are now part and parcel of political discourse. Yet, we did not get here because we were blindsided by a one-off Trumpian shock to the system. And contra certain political voices, defeating Trump will not mark a simple return to normalcy. Trump is, rather, the product of a decades-long process of right-wing political and ideological organizing across all social, political, and cultural fields from which a unique right-wing counter-sphere (cf. Major 2015) has emerged.

In this paper, I critically evaluate this counter-sphere through a focus on what I am calling reactionary technopolitics, or eclectic assemblages of media and communications technologies, political organizations, and hyper-partisan information networks through which right-wing political assemblies are forged, educated, and socialized. As David Neiwert (2017) argues, the political right in the United States occupies an ideological space he calls "Alt-America" (p. 31), or, in Lundskow's (2012) words, a "self-contained reality with rules independent of the truth beyond its boundaries" (p. 530). Within this space, as Jen Schradie (2019) observes, the political right speaks their truth, one that is antithetical to the so-called "mainstream," which includes everything from the popular press, to "politically correct" discourses, to social facts that challenge rightist worldviews. Powering this space are a series of technopolitical entities, from alternative news systems, to well-funded political associations, to informal technologically organized political 
groupings, which constitute a unique right-wing media and political ecosystem existing in its own, autonomous, macrocosm insulated from non-rightist discourses, opinions, and criticisms (Benkler, Faris, and Roberts 2018).

The theoretical backdrop to my analysis is what Jodi Dean (2019) eloquently captures in her articulation of the decline in symbolic efficiency characteristic of contemporary (digital) communicative capitalism: "the loss of shared symbols, of general ideas and norms, of a sense that we know what another means when they appeal to home, the common good, citizenship, the university, etc..." (p. 332). Emanating from the decline in symbolic efficiency is the sense that our agreement on what constitutes authoritative knowledge about reality has been profoundly unsettled-a feeling we express "in everyday language when we say, 'everyone has their own definition.' There is not a shared meaning that one can invoke in a conflict or discussion" (Dean 2019:332). Submerged within the digital, we are now constantly circulating within de-differentiated information flows of breaking news content, memes, political editorializing, and status updates while concurrently being invited online to participate in the construction of our own curated avatars and personal narratives (cf. Agger 2016). Following logically from the decline in symbolic efficiency is an epistemic pessimism that undermines our confidence in the possibility of pursuing real, truthful knowledge, and with it, the spread of a systemic alienation where we feel the world moving along while we stay still. In other words, we experience social change as a "symptom of our powerlessness rather than as the product of our own agency" (Kompridis 2006:247). Worrell (2019) is therefore right to invoke Marx in describing our social condition as one in which "all that is solid melts into air," and to proclaim that "a new fatalism has enslaved us" (p. 49). While the decline in symbolic efficiency normalizes this sense of fatalism, it is not normal. It is a way of being and feeling that had to be learned and imposed through a historical social process_-an important component of which is the subject of this paper.

Below, I outline a critical sociohistorical review of what I see to be the political right's chief contributions to the assault on truth and fact that is reaching its apex under Trumpian governance. I begin by setting the historical stage with a review of how the antidemocratic political project of the neoliberals became intertwined with the popular right-wing reaction against the civil rights, women's liberation, and anti-war movements. What came of this was a political association where free market libertarians formed necessary and effective alliances with social conservatives that materialized as a web of critical, consciousness-shaping political institutions-think tanks, radio and television broadcasts, faux grassroots political organizations, and so on. After providing this historical context, I move on to directly consider the effects of digitization on political reaction, focusing squarely on Trump and the alt-right, and placing the rise of the latter in relation to the cyber-libertarian idealism that has been with the internet since its inception. Guided by this utopian ethos, I show how virtual spaces were exploited by extreme supremacist political groupings. In the final section, I reflect on my argument and outline what I see to be three general-but by no means exhaustive nor mutually exclusive-tendencies: a Trumpian paleoconservative capturing of the Republican Party's base; the degeneracy of the core alt-right into white supremacist terrorism; and the emergence of an internet-powered, politically reactionary "intellectualism" epitomized by the so-called "Intellectual Dark Web" (IDW). I briefly explore what I see to be the chief political significance and cultural meaning of the IDW in our hyper-digital, post-alt-right historical moment, arguing that the felt intellectual authority of the group offers an important sense of objective, stable, and truthful knowledge in the present context of a decline in symbolic efficiency and informational de-differentiation. I conclude by reemphasizing the abnormality of 
our present social juncture and offer brief summary remarks.

Before proceeding, I want to provide a guiding passage that I hope the reader will carry with them through the course of the paper. Corey Robin (2017) argues that political reaction is not a simple reflex; rather, it begins from a position of principle: "that some are fit, and thus ought, to rule others - and then recalibrates that principle in light of a democratic challenge from below" (p. 18). This is a general formula, meaning that both political reaction and the democratic challenge(s) it aims to negate are fungible forms whose substantive contents, discourses, and tactics are filled in differentially by history. An organized reactionary political assemblage provides "a meditation on...the felt experience of having power, seeing it threatened, and trying to win it back" (Robin 2017:4). The power threatened could be that of "a landed estate or the privileges of white skin, the unquestioned authority of a husband or the untrammeled rights of a factory owner," but in all cases, political reaction really does, at the practical level of species-life, "speak to and for people who have lost something," however just that loss may be (Robin 2017:56). But even though reactionary discourses must speak to the material conditions and practical consciousness of a mass public to become an effective political force, the task is always the same: to "appeal to the mass without disrupting the power of elites, or, more precisely, to harness the energy of the mass in order to reinforce or restore the power of elites" (Robin 2017:52). This is the general formula of political reaction - appealing to the mass in order to disenfranchise the mass.

Revealing mass political reaction for what it is-domination, even as it takes on the form of the overwhelming will of the people_-has long been the task of a substantive, critical reason (cf. Worrell 2019). Yet, with the decline of symbolic efficiency, the authority of reason itself- "once used to liquidate unjust domination" —is now "melting away" (Worrell 2019:4). I hope the reader will keep Worrell's (2019) insight in mind, as well as the passage from Robin (2017) quoted above, as they proceed to the analysis below.

\section{| The Historical March of the Right-Wing Media and Political Ecosystem}

Prior to Trump, the alt-right, and generalized fear about the mass disinforming capacities of digital technologies, the far-right had already built vast and formidable political and information networks linking a significant slice of the public to an autonomous nexus of slanted opinion media and political organizations. Some of the earliest foundations for this right-wing media and political ecosystem are to be found in the political reaction to fascism and socialism in the first half of the twentieth century that would coalesce into what has come to be ubiquitously described as neoliberalism. Ray Kiely's (2017) illuminating study of Austrian School social theory and its relation to the rise of neoliberalism is instructive on this point. Kiely (2017) effectively situates what he calls, building on Brown (2015), the "de-democratization" project of neoliberalism within its historical emergence from the crisis period of the 1930s. As Kiely (2017) argues, the profound disdain towards collectivism threaded through the Austrians' political theory was entrenched as the authoritarian assemblages of fascism and Soviet communism rose to prominence. For Mises and Hayek, it was Bolshevism specifically that represented the worst, and inevitable, outcomes of collectivistic governance, both from an economic standpoint in terms of the impossible task of organizing economic calculation through state planning and centralization (cf. Phillips and Rozworski 2019), and from the standpoint of political liberty that sees in communist experiments the tyrannical consequences of states assuming responsibility for the administration of the private lives of citizens. 
This led the Austrians to be dismissive of collectivism tout court, culminating in, as Kiely (2017) evidences in his analysis of Hayek's post-war writings, an unwariness towards democracy itself. Even as social democratic welfare states displaced fascism and fended off communism, the democratic procedures at their core were nevertheless interpreted as being an innately corruptible set of (collectivist) processes through which groups and individuals socialize their private interests and force their wills upon the rest of society in successive blows to individual liberty (Kiely 2017:733). Salvaging liberty from this collectivist onslaught meant, on the one hand, instituting a strict constitutional order with universal, and difficult to change, rules, and, on the other, relegating the exercise of collectivistic wills to an unfettered capitalist marketplace where a "spontaneous order" emerges through the supra-human coordination of people's infinite preferences by omniscient economic powers. The long struggle towards realizing such a "regime of liberty" (Kiely 2017:733) was inaugurated with the founding of the Mont Pelerin Society (MPS) in 1947, an organization that began as a "closed, private members-only debating society" (Mirowski 2014:43), but which would ultimately transform into a crucial space for the construction of neoliberal hegemony.

At its first meeting, the MPS brought together a club of intellectuals committed to its anticollectivist political project. This grouping would become the basis for the formation of what Mirowski (2014) calls the "Neoliberal Thought Collective" (NTC). Importantly, the NTC is not just a network of individuals, but also a "multilevel, multiphase, multisector approach to the building of political capacity to incubate, critique, and promulgate ideas" (Mirowski 2014:43). That is, it is also a political strategy, and one that has been remarkably successful at not only "monopolizing" the political and ideological terrain (Srnicek and Williams 2016:55) through its daunting network of think tanks, academic legitimators, university research centers, and policy houses (Leonard 2019; MacLean 2017), but also at building broad political coalitions with business interests and politicians who, taken together, provide crucial financial and practical support for the NTC (Major 2018; Wasserman 2019). Because the neoliberals were building a robust institutional edifice during the postwar period, they were in prime position to launch a political offensive when the postwar Keynesian consensus was thrust into a legitimacy crisis in the latter half of the twentieth-century (Harvey 2007; Major 2018).

Although the NTC was successful at seizing political and economic control, as Feldmann (2019) argues, politics is never "just a battle for power," but also a struggle over "collective representations and collective identity" (p. 81). Such collective representations form the basis for what Gould (1995) calls "mobilizing ideologies," or "conceptual, 'reduced form"” accounts of the world that identify the "types of social relations...crucial for understanding a set of grievances," and which in turn motivate political struggles to remedy those grievances (p. 16). But as MacLean (2017) observes, neoliberalism faces the problem that it is an elite movement for the capitalist class that could "never win majority support," and it has therefore long depended on subterfuge and esoteric networks to advance its politics (p. xxxiii). Yet, as neoliberalism began radically altering social relations in the twilight of the twentieth century, a popular conservative resurgence was already underway that generated the conditions for a historic alliance of the political rightan alliance from which a general, antigovernment mobilizing ideology would emerge that would foster effective political collaborations among different rightist factions.

This alliance was rooted in the vehement reaction to the civil rights, anti-war, and women's liberation movements of the 1960s and 1970s. What the political right saw in these movements was the corrosion of American tradition and the growth of a tyrannical activist government 
extending special privileges to non-white, non-male communities under the banner of civil rights. Also inspired were Christian fundamentalists, who were revolting against the evils of the timeslegalized abortion, birth control, feminism, and so on-by weaponizing their faith. As Major (2015) shows, in the height of this reaction, the political right turned against the mainstream media for their own ideological "counter-spheres." For these reactionaries, the mainstream media came to be seen as possessing an un-American liberal bias that offered sympathetic coverage to social justice movements while concurrently representing conservatives as ignorant, prejudiced, and socially and politically backwards. Consequently, as Nelson (2019) shows, these disaffected constituencies were redirected by major political players-especially those connected to the powerful Council for National Policy (CNP) — to alternative information feeds fueled by conservative radio stations, cable broadcasts, and partisan publications, while also being organized into a formidable, voting, political force through an array of elite-backed citizens' groups, issuebased advocacy campaigns, and get out the vote drives. ${ }^{1}$

In a strategic decision, the neoliberals would join forces with this blossoming popular reaction, but they had to reckon with its nationalist impulse, which was foremost concerned with defending "American tradition" against unwanted change. On the one hand, nationalism is often at odds with the formal libertarian economics undergirding neoliberalism, which tends to see national-sovereignty as only so many iron walls inhibiting the free flow of capital, contract, and liberty. ${ }^{2}$ On the other hand, the capitalist market is idealized as something that is indifferent to the ascribed characteristics of any person or group, and which distributes wealth and poverty exclusively according to individual capacity. This contradiction was ultimately mediated by the mobilizing ideology of "big government"- a fungible, anti-statist category that can fruitfully be deployed by social conservatives and economic libertarians through its generalist discourse of "freedom, rights, and individual liberty" (Blee and Creasap 2010:273). This "fusionism" of far-right factions, unified by a plastic antigovernment message, became an essential means of justifying neoliberal economic doctrines, on the one hand, and fortifying a socially conservative, non-civil libertarian, political reaction, on the other (Mirowski 2014:39). ${ }^{3}$

With the convergence of right-wing factions, an imposing cache of political resources were made available for large-scale, and long-term, political organizing across multiple social fields and all levels of government (Renton 2019). Crucially, the right mastered the art of astroturf activism by funding, creating, and mobilizing its base into distributed networks of voluntary associations, campus groups, and other political assemblies (Meagher 2012:470). One of the most successful of these efforts is the infamous Americans for Prosperity (AFP), a Koch-backed venture that "has become a massive political-party-like operation" powered by a corps of permanent paid staff stretched across the country and an army of millions of volunteers (Hertel-Fernandez, Skocpol, and Sclar 2018:133). Formal political organizations like AFP greatly expanded the ideological and popular reach of the right, but so did a series of communications deregulations and anti-trust rollbacks largely instituted by the Reagan administration, such as the nullification of the Fairness Doctrine in 1987, which liberated broadcasters from the mandate to provide proportionate air time for opposing viewpoints when covering controversial social and political topics. Such deregulations secured the rise of ultra-partisan media, paved the way for slanted news outlets like Fox News, and did so in the name of free speech and expressive liberty (Nelson 2019).

By the 1990s, a vast, right-wing media and political system were flourishing, but as people were increasingly drawn into the web, it was augmented by rightist digital outposts homesteading their own regions of cyberspace-first the likes of TownHall.com and news aggregators like the 
Drudge Report, but then sites like Breitbart, The Gateway Pundit, and the informal channels of the alt-right. The nodes constituting this sprawling technopolitical network have come to coalesce into a clearly discernible, highly integrated, alternative media and political ecosystem operating in its own ideological universe. In their pathbreaking study of technopolitical information networks, Benkler et al. (2018) show that, while even far-left actors rely upon legacy outlets like the New York Times or Washington Post for their "reality check mechanisms," the right does not. Instead, the right is concentrated within isolated information feeds detached from virtually all non-rightist sources. Consequently, this right-wing ecosystem is extraordinarily self-referential, and its constituents are disproportionately exposed to targeted disinformation campaigns, lies, and what Benkler et al. (2018) describe as "anti-truth propaganda" (cf. Allcott and Gentzklow 2017; Meagher 2012; Neiwert 2017). It is unsurprising, then, that Donald Trump has been able to proficiently exploit this vast ecosystem over the course of his presidential tenure and two campaigns-especially in a period of immense digital pandemonium.

\section{| The Treacheries of Digitization}

The digitization of communications was a boon for political reactionaries and a key factor in Donald Trump's success. Not only did digitization fortify the already existing right-wing media and political ecosystem, but it also created opportunities for the overtly supremacist fringe of the far-right to interject themselves into political deliberation, both directly and by proxy via Trump and his Twitter feed. Indeed, Trump's use of Twitter to "uncontestedly articulate" his political directives radically upended the norms of political communication by allowing him to bypass potentially argumentative interviewers or opponents who might otherwise hold him to account (Engesser et al. 2017:1110). At the same time, these disruptive communications empowered Trump to cultivate an authentic populist appeal through direct and unprocessed invectives that were highly attractive to the growing alt-right-i.e., the now infamous multiplicity of ideologies held together in common opposition to things like "feminism, Islam, the Black Lives Matter movement, political correctness...'globalism,' and establishment politics of both the left and the right” (Wendling 2018:3)—whom, like Trump, hold contempt for hegemonic political norms. To them, Trump communicates an unadulterated authenticity that accomplishes several political goals, as Fieschi (2019) observes:

Authenticity is first and foremost a concept that allows for a politics rooted in instinct rather than reason. It is useful (1) to brand all others as hypocrites; (2) as a blanket excuse to speak one's mind in ways that are disruptive as possible, unbounded by received social and political norms; and (3) to make good on the populist claim that instinct and common sense trump reason and strategy (p. 36).

This guttural appeal contrasts the "unmediated natural intelligence or instinct of the people (who are authentic) with the acquired knowledge, book-learning, and (untrustworthy) sophistication of the elite" (Fieschi 2019:37). The authenticity of the people conveys the fact that their knowledge is closer to reality than the artificial learned knowledge of the universityeducated, and by insinuation, biased liberals penning in the popular press in detached urban enclaves. By taking to Twitter to spout 280 -word tirades, by boasting about "fake news" and the "failing New York Times," by promoting "alternative facts" and castigating the press for their elitism and counterfeit political correctness, Trump became a bullhorn for true Americans, appearing before them as a heroic and honest protagonist unafraid to go to blows with the 
"establishment swamp."

Through Trump, the agents of the alt-right were able to conjure an image of themselves as an "aggrieved 'silent majority" who have finally found a voice, power, and a platform from which to retaliate against a besieging global society (Tuters 2019:46). Unlike a nebulous establishment elite that is accused of selling out the American people to the forces of "globalization, multiculturalism and political correctness" (Kiely 2019:133), Trump articulates his own brand of paleoconservatism that promises to restore the dignity of ordinary Americans by embracing a discourse of economic nationalism, trade protectionism, and immigration restrictionism. ${ }^{4}$ To the paleoconservative, we have long since entered a period of American decline: corporations are multinational entities indifferent towards the livelihood of American workers; the American family and its way of life is being eroded by homosexuality and gender equality; and a global agenda of multicultural egalitarianism is being enforced that fruitlessly compels culturally incompatible groups to live in community with one other as political equals (Worrell 1999). Against this, the "paleo" in paleoconservative implies the possibility of returning to an original way of life conforming with America's true republican tradition (Kiely 2019). Central to this paleo imaginary is the old notion of "producerism," or the drawing of distinctions between "good producers"-e.g., farmers, artisans, and main street entrepreneurs — and "evil parasites" — e.g., bankers and speculators (Lyons 2018:vii). In the modern version, it is the disenfranchised blue-collar manufacturing workers and the modest middle-class whose moral purity and social suffering can be contrasted with that of the decadence and exploitation of globalist elites, as well as that of "illegal" immigrants and the non-producing "underclass" of racialized welfare recipients (Hell and Steinmentz 2017; Kiely 2019; Worrell 1999). Trump's paleo promise to Make America Great Again energized those disaffected by globalization by promising a protectionist political economy at the level of world capitalism, on the one hand, but a purified sphere of restored domestic free-market capitalism, on the other. Trade deals would be renegotiated, tariffs strategically utilized, and the southern border would be fortified with a wall to lockout immigrants. America's productive apparatus would be put to work by and for Americans. The good producers would have their prestige restored, and the globalists would be dethroned.

For all its nationalistic and statist tinges, it is interesting that Trump's paleoconservative discourses resonated with a libertarian wing of the alt-right, specifically a paleolibertarian sect influenced by the Austrian economist and anarcho-capitalist theorist, Murray Rothbard. In a 1992 essay, Rothbard (1992) outlines a libertarian strategy propelled by a program of right-wing populism that does not simply spread "correct ideas" — what Rothbard calls the "Hayek" model in reference to the ideological work of the neoliberals discussed above-but also exposes the "corrupt ruling elites and how they benefit from the existing system, more specifically how they are ripping us off" (p. 8). In a conspicuously racialized invective, Rothbard's populist program calls for authoritarian usages of the state to "take back the streets" from "violent criminals," granting the police the power to administer "instant punishment," and putting "America first" by refusing to support "bums abroad" - a strange set of proposals for an anti-statist libertarian (Rothbard 1992:8-9). ${ }^{5}$ Yet, as the preceding section discusses, and as Sandifer and Graham (2017) further show, this is representative of a broader trend of libertarians aligning themselves with strange bedfellows in the tactical pursuit of liberty. And while both the paleoconservative and paleolibertarian tendencies were historically fringe forces within the American right, from the late 1990s onward, they became popular with a "certain type of geek" and were ideologically nurtured online (Sandifer and Graham 2017:266). What ultimately ensued was the rise of a cyber- 
libertarian idealism that would come to synthesize with more sinister supremacist tendencies, culminating in the alt-right.

The politics, aesthetics, and tactics of the alt-right become clearer when situating their sense of identity threat within the bifurcation of internet socialization that occurred as digital technologies matured and developed. Tuters (2019) insightfully shows how the alt-right has allegiance to what he describes as the "deep vernacular web," or niches of digital communities who "see themselves as an oppositional subculture tasked with keeping alive what they perceive to be the original spirit of the web" (p. 39). That "original spirit of the web" was one initially tethered to the cyber-libertarian idealism, so prevalent in the 1990s, which celebrated the new, liberating, cyber-millennium about to dawn on humankind-one that would elevate all of humanity to an internet-powered techno-utopia that would transcend the coercions of nation states and the oppressions of artificial social hierarchies by inviting all people online to participate as truly equal bodiless subjects on censorship-free platforms where each is, finally, really free to express themselves (Daniels 2015; Golumbia 2016). This authentic, original spirit is epitomized by John Perry Barlow's (1996) famous treatise, A Declaration of the Independence of Cyberspace, where he writes:

Governments of the Industrial World, you weary giants of flesh and steel, I come from Cyberspace, the new home of Mind. On behalf of the future, I ask you of the past to leave us alone... You have no sovereignty where we gather... Ours is a world that is both everywhere and nowhere, but it is not where bodies live. We are creating a world that all may enter without privilege or prejudice accorded by race, economic power, military force, or station of birth. We are creating a world where anyone, anywhere, may express his or her beliefs, no matter how singular, without fear of being coerced into silence or conformity (n.p.).

Of course, as the twenty-first century progressed, this optimistic image was banalized by the cynical realism of platform capitalism less interested in preserving these ideals, let alone in realizing their utopian political visions, than in massifying, monopolizing, and monetizing this emerging technological terrain (Srnicek 2017).

The mainstreaming of computer technologies and the creation of "normie" social media platforms that are accessible, intuitive, and a now naturalized feature of everyday life contrasts sharply with the historical cultures of the internet that were nurtured on BBS boards, Usenet hierarchies, and IRC channels, all of which were initially accessible only to those with at least a modicum of programming competency and computer access-engineers, software developers, technology firms, and the like (Bridle 2018; Bartlett 2016; Turner 2006). But as the internet openedup and changed, those clinging to the "original spirit of the web" found themselves congregating in spaces like 4chan, subreddits, and, eventually, troll social media feeds-all of which would become what Wendling (2018) insightfully calls the "proto-institutions" of the alt-right. Early on, these sites were rendezvous points for nerds, geeks, and gamers to socialize, especially through hazing, humor, and irony in a continuation of the disruptive culture of "flaming" that was popular amongst the earliest denizens of the web (Bartlett 2016:26). Importantly, though, as Massanari (2017) argues, these were very male-centric spaces where a culture of "geek masculinity" flourished, characterized by, on the one hand, an embrace of certain elements of hypermasculinity that valorize "intellect over social or emotional [i.e., feminine] intelligence," while, on the other hand, rejecting hypermasculine traits like physical fitness while also invoking a self-deprecating humor surrounding a stereotypical geeky "awkwardness" (p. 332). This intellectual, yet also lighthearted and masculinist-nerd identity, would, especially by the 2010s, come crashing into other digital 
groupings with alternative understandings of the political possibilities of digital communications and a radically different set of norms and values.

As the internet became a universal social resource, the different platforms populating it could be somewhat accurately categorized according to their political leanings. So, for example, platforms like Tumblr_ —and even Twitter (Wojick and Hughes 2019)_became associated with the left, and particularly, a left that is sensitive to issues of gender, race, privilege, and identity, and which uses the internet to create safe spaces for the discussion and exploration of these topics (Nagle 2017). Within these spaces, a form of activism was developed, which Jane (2016) describes as "digilantism," that tries to empower those injured by oppressive social relations by encouraging them to "call out" or "name and shame" their antagonists (p. 285). As Jane (2016) shows, much of this is targeted at the "e-bile" of misogynistic, racist, and violent verbal attacks and troll campaigns against women, people of color, and LGBTQ people online with the stated intent of holding abusers responsible for their actions and limiting the boundaries of acceptable speech to prevent future episodes of similar conduct. Yet, for those of the "deep vernacular web," this was a threatening, illiberal affront to the internet's original intent and libertarian promise. Even worse, this style of liberal censorship was seen as having become hegemonic, policing speech and expression not just online, but in domains ranging from video games (Massanari 2017), to films and popular culture (Lawson 2018), to the mainstream press (Gardiner 2018).

Curtis Yarvin, a Silicon Valley entrepreneur, programmer, and neo-reactionary (NRx) alt-right progenitor, was instrumental in cultivating concerns about the tyranny of political correctness on his blog, Unqualified Reservations. Under the pseudonym Mencius Moldbug, Yarvin blogged prolifically about what he termed the "Cathedral," a modern day "progressive church" encompassing everything from the press, to the entertainment industry, to universities and beyond that came to constitute a hegemonic, cohesive, "priesthood of culture" (Woods 2019:53). Standing against the Cathedral is the aptly-named "Anti-Cathedral," or those willing to chat and write about "the previously unthinkable" - i.e., politically incorrect ideas - in order to shift the Overton Window (Wendling 2018:33). Similarly, the anti-globalization paleoconservative movement had introduced a homologous category, "cultural Marxism," as a way of framing progressive causes, from multiculturalism to affirmative action, "as foreign to the American way of life" (Woods 2019:40). The fusion of "cultural" with "Marxism" stems from a bizarre conspiracy theory that the Frankfurt School of critical theorists, through their critique of capitalism and its cultural forms in the United States, intended to subvert the nation's traditional values in order to pave the way for a repressive Marxist regime. The late Andrew Breitbart adhered to the conspiracy and amplified its reach through his right-wing news platform, Breitbart News. Presently, as Wendling (2018) observes, the term functions as a catch-all dismissal of any leftist discourses.

Ultimately, these two concepts would become significant political frames guiding alt-right theory and praxis in the spaces of the deep vernacular web. Consequently, Beran (2019) writes, these spaces came to be organized "much like Dante organized hell, in cascading layers of depravity" (p. 140). This polemical description is meant to convey not just that far-right extremists- like neo-Nazis and "race realists" - were hijacking the networks of the deep vernacular web, which they were, but also the way that disparaging and incendiary trolling through memes had come to dominate so much of these networks' cultural expressions in ways that led to, when paired with political content, ideological radicalization. Initially, such activity could be registered as an act of dissent, "doing it for the lulz" as it were, to protest the creeping censorship of digitally mediated speech in a vindication of cyber-libertarianism: no speech should ever be off-limits, 
especially online. For many, this is precisely how they want to be perceived-not as serious racists/sexists/homophobes/etc., but simple trolls stirring banter to elicit an overreaction from progressives in order to demonstrate the latter's illiberalism. But memeing was also understood to be a significant means of genuine political socialization and education. There is even a term used for this process, self-anointed by the alt-right and its converts: red pilling. Red pilling, or taking the red pill, is the process through which one "unlearns" the social engineering of the Cathedral, or the cultural Marxists, or whomever the domineering powers might be (Kelly 2017:75). ${ }^{6}$ And within these online spaces, which were long lacking a coherent political identity beyond a free speech absolutism epitomized by trolling (cf. Beran 2019; Nagle 2017), a profound opportunity presented itself for malevolent, and politically serious, elements to foment a disruptive political reaction.

Importantly, extreme right-wing hate groups joined the cyber-libertarians as some of the earliest adopters of internet-age technologies. BBS, Usenet, IRC, and the world wide web were all variously used by the Klan, neo-Nazis, and others as it became untenable for most of these groups to gather in-person given their advocacy for explicit violence (Levin 2002). Although many of these groups have different, and sometimes even conflictual, histories, much scholarship shows that, online, these groups began cross-fertilizing one another, referencing each other's websites, media, and content, and melting away boundaries (Adams and Roscigno 2005; Back 2002; Burris, Smith, and Strahm 2000). Online communities like Stormfront created crucial spaces for white nationalists of various stripes to debate, discuss, and educate one another (De Koster and Houtman 2008), further dissolving barriers between different reactionary tendencies, and helping to brew what Atton (2006) calls liquid ideologies, or systems of meaning "mobile enough to borrow from a variety of discourses in order to present their arguments" (p. 575). Those professing these liquid ideologies would seep out of the white supremacist web and become what Beran (2019) describes as a "neo-Nazi problem" for sites like 4chan, leading the latter to create a containment board in 2011 called / pol/_ short for "politically incorrect"- to centralize these supremacists and limit their influence over the site (p. 123). The problem was, / pol/ would come to dominate the identity of 4chan, explode in popularity, and transform the image board into ground zero for alt-right politicking. From its depths, a "Great Meme War," guided by a belief in "meme magic" - the idea that hounding digital networks and social media feeds with politically inflammatory memes and media content could cause massive red pilling and "affect the course of history" (Wendling 2018:87)—was waged.

In 2015, Trump entered the political scene as the perfect meme candidate, and his presidential campaign and eventual victory seemed to corroborate the reality of meme magic. Not only did Trump speak and behave like the alt-right by, for example, peddling xenophobic and racist slurssuch as his characterizations of Mexicans as "criminals," "drug dealers," and "rapists"- but he also participated directly in the cultural practices of the alt-right, retweeting racist and anti-Semitic memes originating on 4chan and 8chan-including fake racist crime statistics from a fictional government agency (Wendling 2018) — and even hosting right-wing meme creators at the White House for a so-called "social media summit" in the summer of 2019 (Baca 2019). More recently, Trump trolled teenage environmental activist, Greta Thunberg, after she was named Time's 2019 Person of the Year, by authorizing his official campaign account to tweet a photoshopped image of his head plastered atop of Greta's on her featured Time Magazine cover (Osborne 2019). Like the alt-right and the deep vernacular web, Trump exudes authenticity. He is a real leader unafraid of violating the hegemonic politically correct norms of the Cathedral and the cultural Marxists, 
and his insurgent victory appeared to vindicate the decadent political style of the alt-right and signal the dawn of a new political era. However, not long after Trump's election, internal fissures within the alt-right began splintering the movement apart. Realizing that they could actually win electorally, a faction of the alt-right - the so-called "alt-light" who, though they are contemptuous towards the establishment Republican Party and committed to Trump's economic nationalism, is also worried about violent hardliners within the ranks of the alt-right—struggled to distance themselves from the white supremacists, anti-Semites, and neo-Nazis associated with figureheads like Richard Spencer, much to the chagrin of the latter (Marantz 2019).

Nevertheless, in August of 2017, a "Unite the Right" rally was held in Charlottesville, Virginia that intended to rejuvenate the alt-right's political energy and demonstrate the group's solidarity. Ultimately, though, the neo-Nazis, white supremacists, and alt-righters who descended on the city would provoke clashes with counter-protesters, incite violence, and murder an anti-fascist activist, Heather Heyer. This was a considerable setback for the movement, and a year later, when alt-righters organized a second Unite the Right rally in Washington, DC, less than 30 participants showed, and they were outnumbered by hundreds of counter-protesters (Lopez 2018). At the same time, many alt-right figureheads have since been de-platformed, banned from social media, and removed from crowd-funding platforms like Patreon as demands to curb the spread of altright hate speech and violence intensified (Bowles 2018; Charity 2019). Wendling (2018) is right, therefore, to suggest that the alt-right is in a period of downfall. This is not to claim that the broader political reaction that the alt-right incited is somehow over with-far from it. But it is suggestive that, as the alt-right as we know it crumbles, different modalities of political reaction will fill the void that is left. The question becomes, then, what forms of reaction will take its place?

\section{| Post-Alt-Right Political Reaction: Intellectuals, Ascendant}

As we enter the new decade, I think there are at least three noticeable, but by no means mutually exclusive, trends emerging from the historical trajectories examined in this paper. First, there is a hardening of Trumpian paleo influence among the Republican Party's base that has important implications for mainline conservatism. Here, we see a reactionary turn towards economic nationalism — at least discursively and ideologically_against the degeneration of democracy and material wellbeing under globalized neoliberalism (Boffo, Saad-Filho, and Fine 2018). With respect to the alt-right, it seems to have reached its logical conclusion by devolving to white supremacist terrorism. High profile events, such as the horrifying March 2019 slaughter of Christchurch, New Zealand's Muslim community, during which the terrorist posted a livestream of his rampage to the alt-right board 8chan, epitomize this threat. Recently, the FBI has warned that domestic white supremacist terrorism is on a troubling rise, and, after the El Paso terrorist attack last summer, the Department of Homeland Security conceded that white supremacists are a serious domestic terrorism threat (Dickson 2019; Perez 2019). Yet, there is also another trend quickly gaining influence in the post-Trump, post-alt-right, political and cultural landscape. What I am referring to is the rise of the so-called "Intellectual Dark Web" (IDW), a loose network of dissident academics, online influencers, and public intellectuals running the gamut from Jordan Peterson, to Ben Shapiro, to Dave Rubin, and beyond.

Not unlike many denizens of the alt-right, the IDW is fed up with what they perceive to be a repressive culture of political correctness that prohibits free and intellectually honest discussions about controversial topics (cf. Sikka 2019). Like the alt-right, the IDW lambasts the establishment, 
especially the mainstream media, for engaging in what amounts to censorship by restricting the Overton Window of acceptable discourse in a capitulation to illiberal "social justice warriors." The term itself_-Intellectual Dark Web_-was coined by Eric Weinstein, the Managing Director of Peter Thiel's Thiel Capital, quasi-satirically. Nevertheless, the term stuck, becoming so effectual as to land the IDW a widely read profile by Bari Weiss in the New York Times. In the piece, Weiss (2018) describes the group, and its meaning, thusly:

\begin{abstract}
Here are some things you will hear when you sit down to dinner with the vanguard of the Intellectual Dark Web: There are fundamental differences between men and women. Free speech is under siege. Identity politics is a toxic ideology that is tearing American society apart. And we're in a dangerous place if these ideas are considered "dark"...A decade ago, [the members of the IDW argue], none of these observations would have been considered taboo. Today, people like them who dare venture into this "There Be Dragons" territory on the intellectual map have met with outrage and derision...It's a pattern that has become common in our new era of That Which Cannot be Said and it is the reason the Intellectual Dark Web...came to exist (n.p.).
\end{abstract}

From Weiss' (2018) summary, it is immediately apparent that the IDW is a straightforward reaction against the mainstreaming of certain leftist political sentiments, particularly around issues of gender, race, and privilege that have successfully affected popular discourses in recent years. To the IDW, contemporary progressivism adheres to an anti-rationalist social justice paradigm that pushes a fundamentalist social constructivism. This social constructivism, it is argued, is intellectually legitimated by postmodern philosophy, a school of thought accused of being generalized within the ranks of the left. Accordingly, postmodern subjectivism now shapes progressive common sense and annihilates objectivity in an irrational denial of what are, according to the IDW, basic scientific facts about gender, race, and other human differences. ${ }^{7}$ The IDW, therefore, enters the field as a decidedly rational-scientific counterweight to the supposed irrational excesses of postmodernist left-liberal culture.

The centrality of rationalization to the IDW is epitomized by one of its most famous affiliates, Ben Shapiro. Shapiro routinely lambasts what he calls the "radical subjectivism" of the postmodern left, which, he argues, might make people "feel good" about their identities, but fails to provide "the common framework for a conversation," for, "if we can't agree on the facts, how are we going to have a conversation?" (quoted in Harris 2019). The "New Atheist" Sam Harris further drives the point home, saying, in a conversation with Shapiro, that "identity politics is so toxic, in my view. If identity is paramount, communication is impossible" (Harris 2019). Precisely because they are willing to have such conversations and level such criticisms, the IDW argues that neither they, nor truth itself, can get a fair trial in mainstream culture. They are therefore turning to YouTube, podcasts, and online publishing outlets like Quillette to construct their own alternative communication and information networks where free, unencumbered, and intellectually honest discussion can flourish without overbearing censorship.

However, as the nexus of media constituting the IDW came to cohere into a discernible form, the group was immediately embroiled in controversy. The Guardian (2018) responded to Weiss's (2018) New York Times piece by accusing the IDW of being the "thinking wing of the alt-right." Likewise, those studying the alt-right pointed out how IDW-affiliated influencers were platforming far-right extremists, such as when IDW YouTuber Dave Rubin interviewed Stefan Molyneux, an advocate of race realism, on his web series (Lewis 2018:12). Similarly, the willingness of some IDW affiliates to converse with far-right extremists under the banner of free speech compelled one IDW sympathizer to pen an editorial criticizing this practice (Young 2019). 
Further, a recent piece in The Nation has criticized the IDW's popular e-magazine, Quillette, for repackaging things like discredited race science in a seemingly uncontroversial, "pseudointellectual form" (Minkowitz 2019), and other scholars, using big data metrics, have shown that the audience for IDW content overlaps with those consuming alt-right and alt-light content (Ribeiro et al. 2019). Left-wing political podcaster Michael Brooks (2020) therefore concludes that the IDW "promotoes narratives that either naturalize or mythologize historically contingent power relations" (p. 9). Nevertheless, the IDW strongly rejects the alt-right attribution, largely viewing it as a libelous smear. To this point, Skeptic Magazine recently published an online survey of a purposive sample of IDW members, concluding that the network is dominated by moderate liberals who are concerned about political extremism, free speech, and civil disagreement (Shermer, Saide, and McCaffree 2019). And, as Eric Weinstein (2018) opines on his YouTube channel, "the fact that [the IDW] can't be understood or reported for what it actually is, is in part what we wanted to show you. We wanted to show you the failure of the commentariat" - the latter being the gatekeepers of the mainstream press, cultural commentary, and political editorializing.

A similar disdain for the supposed unreliability of the mainstream is expressed in a video about the IDW by Dave Rubin, where he says that, "I believe almost nothing of real value is happening anywhere in the mainstream media," which, he argues, "masks their opinions as facts" instead of "arming you with real knowledge and new ideas" (The Rubin Report 2018). "Fortunately," Rubin continues, "thanks to YouTube, podcasting, and however else you get shows like this one, the mainstream media's stranglehold on information, which really is a stranglehold on your ability to think clearly about the issues of the day, is crumbling at an incredible rate" (The Rubin Report 2018). Interestingly, in 2019, Rubin announced a deal to bring his famed YouTube series to BlazeTV, a major paid subscription right-wing video streaming platform founded by Glenn Beck, citing "problems with [YouTube] over free speech" (Garcia 2019). ${ }^{8}$ BlazeTV also houses the hugely popular online series Louder With Crowder hosted by conservative comedian and internet celebrity, Steven Crowder. Importantly, on a now-defunct, unofficial website for the IDW - a website IDW mainstays were seemingly aware of (Weiss 2018)_Crowder was identified as a member of the group, specifically its "critical darker web" variant. ' Crowder's identification with the IDW was almost certainly tied to his hugely popular "Change My Mind" video series, a confrontational debate show where he goes to public spaces (generally college campuses), sets up a table, and invites the public (usually undergraduate students) to debate him on the issue of the day, which is printed on a large banner (e.g., "There are Only 2 Genders," "Socialism is Evil," and "Male Privilege is a Myth") along with the invitational tag line, "Change my mind!"

In one of his most popular videos, Crowder (2017) describes the premise of "Change My Mind" this way: "I go on the street...take one given topic, and I just listen to people, let them change my mind, we rationalize our positions, and it's usually really productive." Really, though, the show is based around baiting young progressives into filmed discussions where they are intellectually torn down by Crowder's well-rehearsed, prefabricated rebuttals that "rationally" dissect and lay bare the anti-reason of leftist political arguments. Likewise, one of the IDW's chief thought leaders, Ben Shapiro, has obtained internet fame from his viral videos of him similarly humiliating progressives in choreographed debates. These are public takedowns that are widely shared online, and which have even spawned a meme-destroying someone with "FACTS" and "LOGIC" - that grew out of the punctual stylization of the video titles-e.g., "Ben Shapiro DESTROYS Transgenderism And Pro-Abortion Arguments" and "Ben Shapiro NAILS Hate Speech and Censorship in 2 Minutes”-from Shapiro's official You'Tube channel (cf. Burgis 2019; 
Hughes 2018). ${ }^{10}$ Shapiro is also the author of the hugely popular How to Debate Leftists and Destroy Them: 11 Rules for Winning the Argument, in which, in addition to teaching rightists how to "destroy" leftists in debates, he accuses the latter of variously having an "unearned sense of moral superiority," being "bullies," and being ideologically brainwashed by a detached university professoriate whom have not "had to work a real job" for most of their life (Shapiro 2014). Far less concerned with meaningfully engaging with their opponents, "rational" reactionaries like Shapiro and Crowder are focused on tearing down their adversaries in a humiliating defeat that symbolically reaffirms the intellectual triumph of the right while confirming the intellectual vacuity of the left.

As I make these observations, I am reminded of Adorno's (2005) all too prescient comments on "discussion" from his essay, "Marginalia to Theory and Praxis," particularly where he writes:

...everywhere, discussion is called for...But discussion...has been completely ruined by tactics. What discussions could possibly produce, namely, decisions reached from a greater objectivity to the extent that intentions and arguments interpenetrate, does not interest those who automatically, and in completely inappropriate situations, call for discussion. Each of the hegemonic cliques has prepared in advance the results it desires. Discussion serves manipulation. Every argument, untroubled by the question of whether it is sound, is geared to a purpose. Whatever the opponent says is hardly perceived and then only so that formulaic clichés can be served up in retort (p. 269, emphasis added).

This is a crucial insight, and one that is all too relevant for our hyper-digital present. Within this context, the debate is not meant to honestly mediate sincere intellectual differences, all towards the pursuit of a reasoned consensus. Rather, its intent is to prove the irrationality or unworthiness of one's ideological opponents_and doing so publicly, before an audience. In the age of social media, this often means a virtual public, and an audience numbering in the millions. Ultimately, the soundness, the actual truthfulness, of one's argument is superfluous: what matters is its efficacy as a rationalized rhetorical weapon capable of crippling the Other, all without needing to know the Other's opinion beyond a formalization of its basic propositional structure-and even then just so that it can be knocked down. This turns argument, debate, and discussion into a functional political instrument, as Adorno (2005) further observes:

Either these cliques want to make [the discussing opponent] into something usable by means of engineered discussion... or to discredit them before their followers...The concept of discussion is cleverly twisted so that the opponent is supposed to let himself be convinced; this degrades discussion into a farce (p. 269, emphasis added).

If the opponent cannot be persuaded to concede to their triumphant adversary, then they are meant to be discredited before their adversary's followers. The whole discussion is engineered to ensure the opponent meets defeat — either by a coerced concession, or by public humiliation.

While this style of weaponized rationalism was popular with certain segments of the alt-right (Flisfeder 2018; Sandifer and Graham 2017), I suspect it is going to play an increasingly important role in the hands of groups like the IDW in the coming years. It is also worth stating clearly that I believe there are enough differences between the IDW and the alt-right to warrant analytical distinction. Most notably, I think, is how the IDW aspires to appear as a legitimate rational authority: the IDW wants to be seen as serious and intellectually rigorous. Moreover, while I have highlighted the rightist pull of the IDW, many agents within the network want to appeal to a broad public by tapping into a growing malaise towards some leftist cultural practices and political 
philosophies, like "call out culture," that are inciting backlash from those on both the right and left (Fisher 2013; Lester 2018; Nagle 2017). As reporting by Minkowitz (2019) suggests, the IDW is making progress towards this goal by recruiting influential liberals to opine in places like Quillette. The IDW is thus not a simple extension of the right-wing intelligentsia that has long since been opining in the popular press and news media. Likewise, while I have highlighted some of the IDW's leading personnel in this paper, the boundaries of the IDW are fuzzy, and there is evidence that among the consumers of IDW media, there is a sense that the network includes even amateur content creators committed to the IDW's stated commitments to rationalism, objectivity, and classical liberal values. ${ }^{11}$ For these reasons, rushing to dismiss the IDW as a simple derivative of the alt-right or the right-wing intellectual establishment is an inadequate response. Doing so fails to consider what is genuinely novel about this group and how it differs in important ways from the alt-right and other political assemblages, while also obfuscating the sociohistorical and material conditions from which it emerged.

I think Jodi Dean (2010) captures a particularly trenchant set of social conditions at the heart of our hyper-communicative, digital present, and which are very relevant for assessing the significance of the IDW:

[In communicative capitalism] everyone not only has a right to express an opinion, but each is positively enjoined to-vote, text, comment, share, blog. Constant communication is an obligation....In the setting of communicative capitalism [how] do we know whom to believe or trust? Suspicion or even uncertainty towards expertise goes all the way down... knowledge is now rejected as nothing more than opinion, and opinion which is necessarily limited, biased, and countered by others. The ability to falsify is unlimited. The lack of a capacity to know is the other side of the abundance of knowledge (p. 34-35, some emphasis added).

In internet-powered societies where human socialization is increasingly mediated by social media and totalizing digital technologies, the constant compulsion by these media to share one's opinion, speak their truths, and ceaselessly express themselves has fueled a profound epistemic skepticism that makes agreement on what constitutes truthful knowledge profoundly difficult. In the cacophony of the web, Person A, propounding expertise, promulgates a fact that contradicts Person B's experience; Person B then contradicts Person A by providing a contrary set of facts; Person A responds with yet another contradiction; and so on, ad nauseum-after all, there is always "another survey" — or other data_- "done by another group or association, with whatever bias and whatever methodology, displacing whatever information one thought one had" (Dean 2010:28). At this juncture, the IDW represents an attempt to cut through the seeming nihilistic relativism that is a necessary byproduct of this unlimited capacity to falsify. Whatever its political biases and reactionary functions, to its adherents, the IDW is a comforting reassertion of the possibility of truth — of stable objectivity and fixed meaning in spite of the unsettling sense that we are trapped within a fractured, indeterminate social reality. By creating a space of order in an unordered world, the IDW provides its adherents with access to something that feels like sacred knowledge-truth itself.

\section{| Conclusion}

Here, I have laid out what I hope is a synthetic, critical social history of reactionary technopolitics. The starting point for this inquiry was the premise that the assault on truth and 
fact taking place under Trumpian governance is an abnormal state of affairs for a democratic society, but that it must be situated within the broader social setting of a decline in symbolic efficiency (Dean 2010, 2019). I then proceeded to illustrate the multifaceted ways that the political right contributed to the destabilization of factual and truthful authority through its construction of an autonomous political and media ecosystem powered by an eclectic nexus of information networks and political resources. Motivating that analysis were concerns about the authoritarian implications of a post-truth political order. But, of course, as Hannah Arendt (1972) writes in her seminal essay on the Pentagon Papers, "Lying in Politics," truthfulness "has never been counted among the political virtues, and lies have always been regarded as justifiable tools in political dealings" (p. 4). Even so, as she observes, the secrecy and lies surrounding the Vietnam War and the national security state were made accessible to the entire public in a damning exposé of government corruption, in no small part, Arendt emphasizes, to a fact seeking and truth-telling press (and, it ought to be added, a society presumed to be symbolically efficient and widely capable of agreeing on standards of truth). Yet, she questions whether that most essential political freedom - "the right to unmanipulated factual information without which all freedom of opinion becomes a cruel hoax" (Arendt 1972:45)—would, in the long-run, persist.

In one biting sentence, Worrell (2019) seems to affirm the negative: "If millions of people who are capable of rational thought not only act and think irrationally, but also revel in their irrational self-destruction, it is because the social ground of reality, truth, and reason has been eroded by social disorganization and opportunistic demagogues" (p. 54). This is not a normal state of affairs for a democratic society, whose ideals presume the sort of unmanipulated factual information Arendt sees as so central to substantive political freedom, and whose practical realization depends upon applying this information to the collective pursuit of — as C. Wright Mills ([1959] 2000) puts it- "reasoned moral choice" (p. 117). But with declining symbolic efficiency comes the declining authority of truth itself, threatening to leave us with "nothing more than power politics, rebellion, rationalizations, [and] propaganda" (Worrell 2019:9). With Trump and the alt-right, this threat makes itself conspicuous. But as I have shown, it was the convergence of several reactionary forces, many of which long preceded Trump and the alt-right, whose interlacing were essential in routing society towards our present conundrum.

I chose to focus on the IDW in the final section of the paper due to its attempts to assert itself as a truth-seeking authority amidst the decline in symbolic efficiency. It provides a way out of the relativist anguish of the historical present by postulating a realism in unrealistic times - a compelling offer in a moment of profound epistemic pessimism. Yet, it is one that risks legitimizing essentialist and inegalitarian political agendas by too comfortably finding common ground with an online ecosystem of reactionary "rationalists" who lump struggles for political equality "in with creationism as an absurd delusion, and claim to debunk feminism and other such ideas...using 'logic' and 'reason' and 'facts,' etc." (Sandifer and Graham 2017:282). Rationalistic rhetoric and historically decontextualized factual evidence have long been used to engage in the "rationalization of Othering," and therefore the justification of social inequality and political domination (Sakki and Pettersson 2016:162). This is because, as Arendt (1972) reminds us: "Factual truths are never compellingly true...Facts need testimony to be remembered and trustworthy witnesses to be established in order to find a secure dwelling place in the domain of human affairs" (p. 6). Compelling testimony thus establishes truthful authority. But now more than ever, there are a multiplicity of convincing yet divergent testimonies emanating from the same set of facts, and such testimonies can be used to establish truthful authorities that rationalize all sorts of 
political conclusions-progressive or regressive (cf. Daniels 2009).

Worrell (2019) thus writes that it is the task of disobedient radicals to probe "the lines of authority" to discover "what is rational and what is bunkum" (p. 6). While skepticism towards authoritative truth claims now goes all the way down and our capacity to falsify any set of truth of claims with another set is seemingly infinite (Dean 2010), it is simply false that any explanation is as good as another and that we cannot find reasonable epistemic grounds from which to scrutinize and discriminate against competing explanations for social phenomena. ${ }^{12}$ It is the task of disobedient radicals to find such ground amidst the flurry of surplus information vying for our attention and belief in our highly reactionary and hyper-digital historical present. As Bonefeld (2016) puts it, there "is only one reality, and that is the reality of the existent social relations" (p. 5). Not even the socially constructed world is infinitely pliable, and the reality of society as it is constituted at any historical juncture "puts limits on knowledge so that not all interpretations are equally plausible" (McCall 2005:1793). The efficacy of reactionary political struggles is dependent upon the mystification of the reality of the social relations in which we find ourselves. Slicing through this mystification presumes a critical realist orientation that places limits on the ontologically possible — and therefore theoretically reasonable — at any historical moment (cf. Bhaskar 2015). In the words of Marx ([1845] 2010):

All social life is essentially practical. All mysteries which lead theory to mysticism find their rational solution in human practice and in the comprehension of this practice (p. 5).

\section{Endnotes}

1. An important component of this was what Nelson (2019) describes as a media drought throughout vast swaths of the country, especially in the latter half of the twentieth-century, as small local papers and radio stations were forced to close under the weight of financial pressure. The reactionary right stepped in, filling this void with a litany of biased media in what would prove to be a prescient political maneuver.

2. I say "formal" because the class of capital has wedded itself to a project of repurposing, not disposing of, the state to advance its political economic interests (Boggs 2012).

3. It is important to note that for some of the devout libertarians operating within this rightwing coalition, they will often disagree with the social conservatives on their traditionalist social norms. However, as Hertel-Fernandez et al. (2018) show, as a practical matter, the libertarians at the heart of the neoliberal enterprise nevertheless do find themselves allying with exactly these social conservatives in order to advance their economic interests. For example, while the Koch's strongly disapproved of Donald Trump during the 2016 presidential election, they nevertheless have found themselves hosting supporters of Trump at their biannual seminars (Hertel-Fernandez et al. 2018:150).

4. The primary consideration here is on discourse and ideology. Whether or not Trump has been, in practice, a committed paleoconservativeis more nuanced (cf. Boffo et al. 2018; Kiely 2019; Matthews 2016).

5. In the same essay, Rothbard laments the political establishment's undermining of Klansmen David Duke's campaign for governor of Louisiana.

6. The red pill is a metaphor that comes from the film The Matrix, a reference to the scene where Neo is offered to the opportunity of taking a red or blue pill. The former will reveal to him the reality of the matrix; the latter will allow him to continue within it in blissful ignorance. 
7. See, for example, Jordan Peterson's lecture on "Postmodern NeoMarxism: Diagnosis and Cure": https://www.youtube.com/watch?v=s4 c-jOdPTN8.

8. Even so, the show still airs on YouTube, but Blaze'TV subscribers do get special perks like early access to streams.

9. While the site is no longer up and running, it is still accessible via the Way Back Machine: https:/ / web.archive.org/web/20190525044439/http:// intellectualdark.website/steven-crowder/. Other sites for the IDW have since popped up, including a social media platform for IDW fans (https://idw.community), as well as another unofficial informational page for the group (https://intellectualdarkweb.site/).

10. See the "Ben Shapiro Highlights" play list on YouTube: https://www.youtube.com/p laylist?list=PLX_rhFRR1AG5-1MA4JAe6dZ mBBF9dIBEm.

11. For example, a recent master's thesis in philosophy criticizing "the ethics of compelled pronouns and the epistemology of "me, too"” includes in its acknowledgements a nod to amateur content creators like Tim Poolwhose "independent, consistent, and honest journalism," the author writes, "provided me with insights into the culture war that claims rationality as its first victim," as well as to the famed YouTuber Carl Benjamin (better known as Sargon of Akkad) and his "relentless defense of classical liberal ideals" just before the author names the Intellectual Dark Web directlythose "who champion rational discourse above all else" —and thanks Jordan Peterson and Dave Rubin for their influence on the author's own intellectual development (Gustafson 2019:ix). Similarly, on the unofficial IDW social network site-https://idw.community-there are fan groups for Pool, Benjamin, and others, including Stefan Molyneux. This inclusion of amateurs and independent content creators differentiates the IDW from the establishment intelligentsia of both the right and left, while also, I'd argue, in agreement with Lewis (2018), endowing it with an authentic-even grassroots-energy and techno-youthful aesthetic.

12. Ironically, this is a point similarly emphasized by the IDW for radically different epistemic, ethical, and political purposes than those of interest to a critical sociology (see the video referenced in note 7 above).

\section{References}

Adams, J. and V. J. Roscigno. 2005. "White Supremacists, Oppositional Culture and the World Wide Web." Social Forces 84(2):759-778.

Adorno, Theodor W. 2005. "Marginalia to Theory and Praxis." Pp. 259-278 in Critical Models: Interventions and Catchwords. New York: Columbia University Press.

Agger, Ben. 2016. Speeding Up Fast Capitalism. New York: Routledge.

Allcott, Hunt and Matthew Gentzkow. 2017. "Social Media and Fake News in the 2016 Election." Journal of Economic Perspectives 31(2):211-236.

Arendt, Hannah. 1972. Crises of the Republic. New York: Harcourt Brace \& Company.
Back, Les. 2002. "Aryans Reading Adorno: Cyber-Culture and Twenty-First Century Racism." Ethnic and Racial Studies 25(4):628-651.

Barlow, John Perry. 1996. "A Declaration of the Independence of Cyberspace." Electronic Frontier Foundation. Accessed December 10, 2019 (https:// www.eff.org/cyberspace-independence).

Bartlett, Jamie. 2016. The Dark Net: Inside the Digital Underworld. New York: Melville House.

Benkler, Yochai, Robert Faris, and Hal Roberts. 2018. Network Propaganda: Manipulation, Disinformation, and Radicalization in American Politics. New York: Oxford University Press. 
Beran, Dale. 2019. It Came from Something Awful: How a Toxic Troll Army Accidentally Memed Donald Trump into Office. New York: All Points Books.

Bhaskar, Roy. 2015. The Possibility of Naturalism: A Philosophical Critique of the Contemporary Human Sciences. 4th ed. New York: Routledge.

Blee, Kathleen M. and Kimberly A. Creasap. 2010. "Conservative and Right-Wing Movements." Annual Review of Sociology 36:269-286.

Boffo, Marco, Alfredo Saad-Filho, and Ben Fine. 2018. "Neoliberal Capitalism: The Authoritarian Turn." Socialist Register 55:247-270.

Boggs, Carl. 2019. “The 'Big Government' Mythology." Fast Capitalism 9(1):35-37.

Bonefeld, Werner. 2016. Critical Theory and the Critique of Political Economy: On Subversion and Negative Reason. New York: Bloomsbury Academic.

Bowles, Nellie. 2018. "Patreon Bars Anti-Feminist for Racist Speech, Inciting Revolt." The New York Times, December 24. Accessed March 11, 2020 (https:// www.nytimes.com/2018/12/24/technology/patreon-hate-speech-bans.html).

Bridle, James. 2018. New Dark Age: Technology and the End of the Future. New York: Verso.

Brooks, Michael. 2020. Against the Web: A Cosmopolitan Answer to the New Right. Winchester, UK: Zero Books.

Brown, Wendy. 2015. Undoing the Demos: Neoliberalism's Stealth Revolution. New York: Zone Books.

Burgis, Ben. 2019. Give Them an Argument: Logic for the Left. Winchester, UK: Zero Books.

Burris, Val, Emery Smith, and Ann Strahm. 2000. "White Supremacist Networks on the Internet." Sociological Focus 33(2):215-235.

Charity, Justin. 2019. "Is There Life After the Alt-Right?" The Ringer, May 8. Accessed December 12, 2019 (https://www.theringer.com/2019/5/8/18535929/ alt-right-katie-mchugh-deplatform-milo-yiannopoulos-facebook-youtube-glenn-beck).

Crowder, Steven. 2017. "Hate Speech Isn't Real |Change My Mind." YouTube, Accessed December 26, 2019 (https://www.youtube.com/ watch?v=Q0hPd2gMlGw).

Dale, Daniel. 2019. "Donald Trump Has Now Said More than 5,000 False Things as President." Toronto

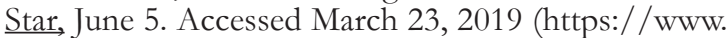
thestar.com/news/world/analysis/2019/06/05/donald-trump-has-now-said-more-than-5000-false-claimsas-president.html).
Daniels, Jessie. 2009. "Cloaked Websites: Propaganda, Cyber-Racism and Epistemology in the Digital Era." New Media \& Society 11(5):659-683.

Daniels, Jessie. 2015. “My Brain Database Doesn't See Skin Color': Color-Blind Racism in the Technology Industry and in Theorizing the Web." American Behavioral Scientist 59(11):1377-1393.

Dean, Jodi. 2010. "Affective Networks." MediaTropes 2(2):19-44.

Dean, Jodi. 2019. "Communicative Capitalism and Revolutionary Form." Millennium: Journal of International Studies 47(3):326-340.

Dickson, E. J. 2019. "Dept. of Homeland Security Names White Supremacy a Domestic Terrorist Threat." Rolling Stone. Accessed December 16, 2019 (https://www.rollingstone.com/culture/culture-news/ homeland-security-white-supremacy-domestic-terrorism-threat-888748/).

Engesser, Sven, Nicole Ernst, Frank Esser, and Florin Büchel. 2017. "Populism and Social Media: How Politicians Spread a Fragmented Ideology.” Information, Communication \& Society 20(8):1109-1126.

Feldmann, Tony Allen. 2019. "Divining Domination: Steve Bannon as a Political Mystagogue." Fast Capitalism 16(2):77-86.

Fieschi, Catherine. 2019. Populocracy: The Tyranny of Authenticity and the Rise of Populism. Newcastle, UK: Agenda Publishing.

Fisher, Mark. 2013. "Exiting the Vampire Castle." openDemocracy, November 24. Accessed March 24, 2020 (https://www.opendemocracy.net/en/ opendemocracyuk/exiting-vampire-castle/).

Flisfeder, Matthew. 2018. "'Trump'-What Does the Name Signify? Or, Protofascism and the Alt-Right." Cultural Politics 14(1):1-19.

Gallup. 2020. "Presidential Approval Ratings-Donald Trump.” Accessed March 11, 2020. (https://news. gallup.com/poll/203198/presidential-approval-ratings-donald-trump.aspx).

Garcia, Carlos. 2019. "Breaking: Dave Rubin Bringing The Rubin Report to BlazeTV." TheBlaze September 3. Accessed December 26, 2019 (https://www.theblaze. $\mathrm{com} /$ news/dave-rubin-is-bringing-his-show-to-blaze-tv).

Gardiner, Becky. 2018. "'It's a Terrible Way to Go to Work:' What 70 Million Readers' Comments on The Guardian Revealed About Hostility to Women and Minorities Online." Feminist Media Studies 18(4):592-608.

Golumbia, David. 2016. The Politics of Bitcoin: Software as Right-Wing Extremism. Minneapolis, MN: University of Minnesota Press. 
Gould, Roger. 1995. Insurgent Identities: Class, Community, and Protest in Paris from 1848 to the Commune. Chicago: University of Chicago Press.

Gustafson, Thomas Eric. 2019. "An Analytical Critique of Postmodern Social Movements: The Ethics of Compelled Pronouns and Epistemology of 'Me, Too." M.A. thesis, Department of Philosophy, San Diego State University, San Diego, CA.

Harris, Sam. 2019. "Making Sense with Sam Harris \#112 - The Intellectual Dark Web (with Eric Weinstein and Ben Shapiro)." YouTube, Accessed December 18, 2019 (https://www.youtube.com/watch?v=jzXePwgeIBI).

Harvey, David. 2007. A Brief History of Neoliberalism. New York: Oxford University Press.

Hertel-Fernandez, Alexander, Theda Skocpol, and Jason Sclar. 2018. "When Political Mega-Donors Join Forces: How the Koch Network and the Democracy Alliance Influence Organized U.S. Politics on the Right and Left." Studies in American Political Development 32(2):127-165.

Hughes, Adam and Stefan Wojick. 2019. "10 Facts about Americans and Twitter." Pew Research Center, August 2. Accessed December 16, 2019 (https://www.pewresearch.org/fact-tank/2019/08/02/10-facts-aboutamericans-and-twitter/).

Hughes, Brian. 2018. "Analyzing YouTube 'Rekt' Videos as a Vector for Radicalization." Center for Analysis of the Radical Right, August 30. Accessed December 17, 2019 (https://www.radicalrightanalysis.com/2018/08/30/analyzing-youtube-rekt-videos-as-a-vector-for-radicalization/).

Jane, Emma A. 2016. "Online Misogyny and Feminist Digilantism." Continuum 30(3):284-297.

Kelly, Annie. 2017. “The Alt-Right: Reactionary Rehabilitation for White Masculinity." Soundings 66:68-78.

Kiely, Ray. 2017. "From Authoritarian Liberalism to Economic Technocracy: Neoliberalism, Politics and 'De-Democratization." Critical Sociology 43(4-5):725-745.

Kiely, Ray. 2019. "Locating Trump: Paleoconservatism, Neoliberalism, and Anti-Globalization." Socialist Register 55:126-149.

Kompridis, Nikolas. 2006. Critique and Disclosure: Critical Theory Between Past and Present. Cambridge, MA: The MIT Press.

Lawson, Caitlin E. 2018. "Platform Vulnerabilities: Harassment and Misogynoir in the Digital Attack on Leslie Jones." Information, Communication \& Society 21(6):818-833.
Leonard, Christopher. 2019. Kochland: The Secret History of Koch Industries and Corporate Power in America. New York: Simon \& Schuster.

Lester, Amelia. 2018. "The Voice of the 'Intellectual Dark Web."” POLITICO Magazine, November 11. Accessed December 18, 2019 (https://politi. co/2JVltGO).

Lewis, Rebecca. 2018. Alternative Influence: Broadcasting the Reactionary Right on YouTube. New York: Data \& Society Research Institute. Accessed December 19, 2019 (https://datasociety.net/wp-content/uploads/2018/09/DS_Alternative_Influence. pdf).

Lopez, German. 2018. "Unite the Right 2018 Was a Pathetic Failure.” Vox, August 12. Accessed December 19, 2019 (https://www.vox.com/identities/2018/8/12/17681444/ unite-the-right-rally-dc-charlottesville-failure).

Lundskow, George. 2012. "Authoritarianism and Destructiveness in the Tea Party Movement." Critical Sociology 38(4):529-547.

Lyons, Matthew N. 2018. Insurgent Supremacists: The U.S. Far Right's Challenge to State and Empire. Oakland, CA: PM Press.

MacLean, Nancy. 2017. Democracy in Chains: The Deep History of the Radical Right's Stealth Plan for America. New York: Penguin Books.

Major, Aaron. 2018. "Ideas Without Power." Catalyst: A Journal of Theory \& Strategy 2(3):47-81.

Major, Mark. 2015. “Conservative Consciousness and the Press: The Institutional Contribution to the Idea of the 'Liberal Media' in Right-Wing Discourse." Critical Sociology 41(3):483-491.

Marantz, Andrew. 2019. Antisocial: Online Extremists, Techno-Utopians, and the Hijacking of the American Conversation. New York: Viking.

Marx, Karl. [1845] 2010. “Theses on Feuerbach.” Pp. 3-5 in Marx \& Engels Collected Works, Vol. 5, London: Lawrence \& Wishart.

Massanari, Adrienne. 2017. “\#Gamergate and The Fappening: How Reddit's Algorithm, Governance, and Culture Support Toxic Technocultures." New Media \& Society 19(3):329-346.

Matthews, Dylan. 2016. "Paleoconservatism, the Movement that Explains Donald Trump, Explained.” Vox, May 6. Accessed May 18, 2020 (https://www.vox.com/2016/5/6/11592604/ donald-trump-paleoconservative-buchanan).

McCall, Leslie. 2005. "The Complexity of Intersectionality.” Signs 30(3):1771-1800.

Meagher, Richard. 2012. "The "Vast Right-Wing Conspiracy': Media and Conservative Networks." New Political Science 34(4):469-484. 
Mills, C. Wright. [1959] 2000. The Sociological Imagination. New York: Oxford University Press.

Minkowitz, Donna. 2019. "Why Racists (and Liberals!) Keep Writing for Quillette.” December 5. Accessed December 19, 2019 (https://www.thenation.com/ article/quillette-fascist-creep/).

Mirowski, Philip. 2014. Never Let a Serious Crisis Go to Waste: How Neoliberalism Survived the Financial Meltdown. New York: Verso.

Nagle, Angela. 2017. Kill All Normies: Online Culture Wars From 4Chan and Tumblr to Trump and the AltRight. Winchester, UK: Zero Books.

Neiwert, David. 2017. Alt-America: The Rise of the Radical Right in the Age of Trump. New York: Verso.

Nelson, Anne. 2019. Shadow Network: Media, Money, and the Secret Hub of the Radical Right. New York: Bloomsbury Publishing.

Perez, Evan. 2019. “FBI Has Seen Significant Rise in White Supremacist Domestic Terrorism in Recent Months." CNN, June 28. Accessed December 16, 2019 (https://www.cnn.com/2019/05/23/politics/ fbi-white-supremacist-domestic-terror/index.html).

Phillips, Leigh and Michal Rozworski. 2019. The People's Republic of Walmart: How the World's Biggest Corporations Are Laying the Foundation for Socialism. New York: Verso.

Renton, David. 2019. The New Authoritarians: Convergence on the Right. London: Pluto Press.

Ribeiro, Manoel Horta, Raphael Ottoni, Robert West, Virgílio A. F. Almeida, and Wagner Meira. 2019. "Auditing Radicalization Pathways on YouTube." arXiv:1908.08313. Accessed December 19, 2019 (http://arxiv.org/abs/1908.08313).

Robin, Corey. 2017. The Reactionary Mind: Conservatism from Edmund Burke to Donald Trump. 2nd edition. New York: Oxford University Press.

Rothbard, Murray. 1992. "Right-Wing Populism: A Strategy for the Paleo Movement." Triple-R January 1992:5-14.

Sakki, Inari and Katarina Pettersson. 2016. "Discursive Construction of Otherness in Populist Radical Right Political Blogs.” European Journal of Social Psychology 46:156-170.

Sandifer, Elizabeth and Jack Graham. 2017. "No Law for the Lions and Many Laws for the Oxen is Liberty: A Subjective Calculation of the Value of the Austrian School." Pp. 235-302 in Neoreaction a Basilisk: Essays on and Around the Alt-Right, edited by E. Sandifer. Eruditorum Press.
Schradie, Jen. 2019. The Revolution That Wasn't: How Digital Activism Favors Conservatives. Cambridge, MA: Harvard University Press.

Shapiro, Ben. 2014. How to Debate Leftists and Destroy Them: 11 Rules for Winning the Argument. Sherman Oaks, CA: David Horowitz Freedom Center.

Shermer, Michael, Anondah Saide, and Kevin McCaffree. 2019. "Shedding Light on the Intellectual Dark Web: A Preliminary Empirical Study." Skeptic, October 20. Accessed October 30, 2019 (https://www. skeptic.com/reading_room/preliminary-empirical-study-shedding-light-on-intellectual-dark-web/).

Sikka, Tina. 2019. "The Foodways of the Intellectual Dark Web: To 'Meat' or not to 'Meat'.' Social Politics Summer 2019:1-25.

Srnicek, Nick and Alex Williams. 2016. Inventing the Future: Postcapitalism and a World Without Work. New York: Verso.

Srnicek, Nick. 2017. Platform Capitalism. Malden, MA: Polity.

The Guardian. 2018. “The 'Intellectual Dark Web'the Supposed Thinking Wing of the Alt-Right." The Guardian, May 9. Accessed December 17 (https:// www.theguardian.com/politics/shortcuts/2018/ may/09/the-ntellectual-dark-web-the-supposed-thinking-wing-of-the-alt-right).

The Rubin Report. 2018. "What is The Intellectual Dark Web? | DIRECT MESSAGE | Rubin Report." YouTube, January 30. Accessed December 17, 2019 (https://www.youtube.com/watch?v $=\mathrm{n} 5 \mathrm{HN}-\mathrm{K}$ T9rj0).

Tuters, Marc. 2019. "LARPing \& Liberal Tears: Irony, Belief and Idiocy in the Deep Vernacular Web." Pp. 37-48 in Post-Digital Cultures of the Far Right: Online Actions and Offline Consequences in Europe and the US, edited by M. Fielitz and N. Thurston. Bielefeld, Germany: transcript Verlag.

Wasserman, Janek. 2019. The Marginal Revolutionaries: How Austrian Economists Fought the War of Ideas. New Haven, CT: Yale University Press.

Weinstein, Eric. 2018. 'Why the 'Intellectual Dark Web' Has Such a Crazy Name.” YouTube, June 7. Accessed December 17, 2019 (https://www.youtube.com/ watch? $=$ cr0OX6ai4Qw).

Wendling, Mike. 2018. Alt-Right: From 4Chan to the White House. London: Pluto Press.

Woods, Andrew. 2019. "Cultural Marxism and the Cathedral: Two Alt-Right Perspectives on Critical Theory." Pp. 39-60 in Critical Theory and the Humanities in the Age of the Alt-Right, edited by C. M. Battista and M. R. Sande. Cham, Switzerland: Palgrave Macmillan. 
Worrell, Mark P. 1999. “The Veil of Piacular Subjectivity: Buchananism and the New World Order." Electronic Journal of Sociology 4(3): https:/ / www.sociology.org/ content/vol004.003/buchanan.html.

Worrell, Mark P. 2019. The Sociogony: Social Facts and the Ontology of Objects, Things, and Monsters. Boston, MA: Brill.

Young, Cathy. 2019. "How the IDW Can Avoid the Tribalist Pull." Quillette. Accessed December 16, 2019 (https://quillette.com/2019/05/24/ how-the-idw-can-avoid-the-tribalist-pull/). 